\title{
Fish Assemblages, Growth Pattern and Environmental Factors in Upper Baleh River, Kapit, Sarawak
}

\author{
LEE NYANTI*1 ${ }^{*}$, NUR EZAIMAH IDRIS ${ }^{1}$, HAFIDA BOLHEN ${ }^{1}$, JONGKAR GRINANG ${ }^{2}$, \\ TECK-YEE LING ${ }^{1}$, SIONG-FONG SIM ${ }^{1}$, CHEN-LIN SOO ${ }^{1}$, TONNY GANYAI ${ }^{3}$ \& KAREN \\ LEE-SUAN PING ${ }^{3}$
}

\author{
${ }^{1}$ Faculty of Resource Science and Technology, Universiti Malaysia Sarawak, 94300 Kota Samarahan, \\ Sarawak, Malaysia; ${ }^{2}$ Institute of Biodiversity and Environmental Conservation, Universiti Malaysia \\ Sarawak, 94300 Kota Samarahan, Sarawak, Malaysia; ${ }^{3}$ Research and Development Department, \\ Sarawak Energy Berhad, 93050 Kuching, Sarawak, Malaysia \\ *Corresponding author: nyantilee2@gmail.com \\ Received: 19 March $2019 \quad$ Accepted: 15 April 2019 \\ Published: 31 June 2019
}

\begin{abstract}
A survey of the freshwater fish composition in the upper Baleh River, Sarawak was conducted in 2015. A total of 1,538 specimens, comprising 45 species from nine families were collected using electrofishing devices and cast nets. The family Cyprinidae was the most dominant $(62.9 \%)$ as well as diverse $(42.2 \%)$ family, followed by the Balitoridae $(31.0 \% ; 31.1 \%)$ in the river. The three most dominant species were Tor tambra $(18.1 \%)$, Lobocheilos ovalis (12.9\%), and Parhomaloptera microstoma (11.3\%). Shannon's diversity index, Margalef's richness index, and Pielou's evenness index were 2.9, 6.0, and 0.8, respectively, an indication of moderate species diversity. Canonical Correspondence Analysis demonstrate that elevation, stream order and sedimentation were the most significant factors related to fish assemblages in the river, particularly for members of the families Cyprinidae and Balitoridae. The coefficient ' $\mathrm{n}$ ' value in length-weight relationship for T. tambra, L. ovalis, and P. microstoma were determined as $2.92,2.72$, and 3.15 , respectively. T. tambra and $L$. ovalis exhibited a negative allometric growth pattern which could be due to food competition whereas $P$. microstoma exhibited a positive allometric growth pattern as mountainous forest stream habitat offers favourable environmental conditions. The Fulton's condition factor of each species indicates that $T$. tambra and $L$. ovalis were in poor condition, whereas $P$. microstoma was in extremely poor condition. It is hypothesized that environmental degradation caused by logging activities have affected the health of the most dominant fish species in the upper Baleh River. Further study should be conducted to determine the underlying factors that are affecting the fish diversity.
\end{abstract}

Keywords: biological indices, Canonical Correspondence Analysis, condition factor, Cyprinidae, length-weight relationship,

Copyright: This is an open access article distributed under the terms of the CC-BY-NC-SA (Creative Commons Attribution-NonCommercial-ShareAlike 4.0 International License) which permits unrestricted use, distribution, and reproduction in any medium, for non-commercial purposes, provided the original work of the author(s) is properly cited.

\section{INTRODUCTION}

Since the pioneering work of Lelek (1987), the documentation of freshwater fishes in Sarawak has been undertaken continuously (Nyanti et al., 1999; Inger \& Chin, 2002; Parenti \& Lim 2005; Jeffrine et al., 2009; Khairul Adha et al., 2009; Nasarudin et al., 2010). There are over 600 species of freshwater fish in Malaysia (Froese \& Pauly, 2016), and approximately 254 freshwater fish species have been recorded in Sarawak (Kottelat \& Lim, 1995; Atack, 2006). However, knowledge on fish assemblages in Sarawak's river is still patchy, as the surveys have been mostly restricted to major rivers in Sarawak (Parenti \& Lim, 2005). Due to the difficulties in conducting research in rural areas of Sarawak, studies on the fish assemblages in the upper part of forest streams remain scarce.

A recent study has shown that forest streams in Sarawak are subjected to sedimentation problem, due to logging activities (Ling et al., 2016). Fish fauna composition is greatly affected by environmental change caused by natural or anthropogenic factors (Dudgeon, 2000). Teresa et al. (2015) demonstrated that changes in habitat, food resources, and physicochemical conditions affect fish community structure in the deforested areas. Freshwater fishes are also facing major extinction risk due to those uncontrolled developments (Kottelate \& Whitten 
1996). Therefore, studies on the fish assemblages in the disturbed forest stream, coupled with growth patterns and well-being of fishes in streams are crucial.

The Baleh River is the left representative tributary of the Rajang River - the longest river in Sarawak. A national park with an area of approximately 66,000 ha has been proposed at approximately $182 \mathrm{~km}$ from the mouth of the Baleh River. Data on fish species composition and distribution in these upstream areas are lacking. The growth pattern and well-being of fishes in this forest stream are topics that remain unstudied. Hence, this study aimed to establish the baseline data on fish fauna composition in the upper Baleh River associated with environmental parameters in the stream. The length-weight relationship and Fulton condition factor of the three most dominant fish species were also determined in the present study.

\section{MATERIALS AND METHODS}

Field samplings were conducted at 23 stations (Station 1 to Station 23), located along the upper Baleh River in April and November 2015. Three stations were located at upper (Station 1), middle (Station 15), and lower (Station 21) parts of the main river, while 20 stations were located at tributaries (Figure 1). Fish samples were collected using an electrofishing device consisting of two copper electrodes on wooden handle and powered by a 1000-watt portable generator (Stephill SHX1000 KVA Honda). Stunned fishes were collected using scoop nets (40 $\mathrm{cm}$ by $35 \mathrm{~cm}$ frame, $1 \mathrm{~cm}$ mesh size). The electroshocking process was carried out for 30 to 45 minutes and the area of sampling varied with the width of the stream and accessibility. When no fishes were caught, electroshocking distance was increased up to a maximum distance of 150 m. Besides electrofishing device, cast nets (height $=280 \mathrm{~m}$; diameter $=240 \mathrm{~cm}$; mesh size $=$ $2 \mathrm{~cm}$ ) were used to collect fishes from shallow pools. The environmental parameters were measured concurrently with the sampling of fish. Temperature, dissolved oxygen (DO), turbidity, $\mathrm{pH}$, and conductivity of streams were measured by using a multi-parameter Sonde (YSI 6820 V2). Elevation was taken using a Portable Global Positioning System (Garmin GPSmap 62Sc). Physical stream habitat was characterized following Barbour et al. (1996) and Iwata et al. (2003). The habitats in the upper Baleh River consist of partially shaded stream with sediment substrates, fallen branches, as well as rocky bottom streams. Sedimentation, canopy cover, and order of streams were recorded. Scores were given based on the condition of stream habitat.

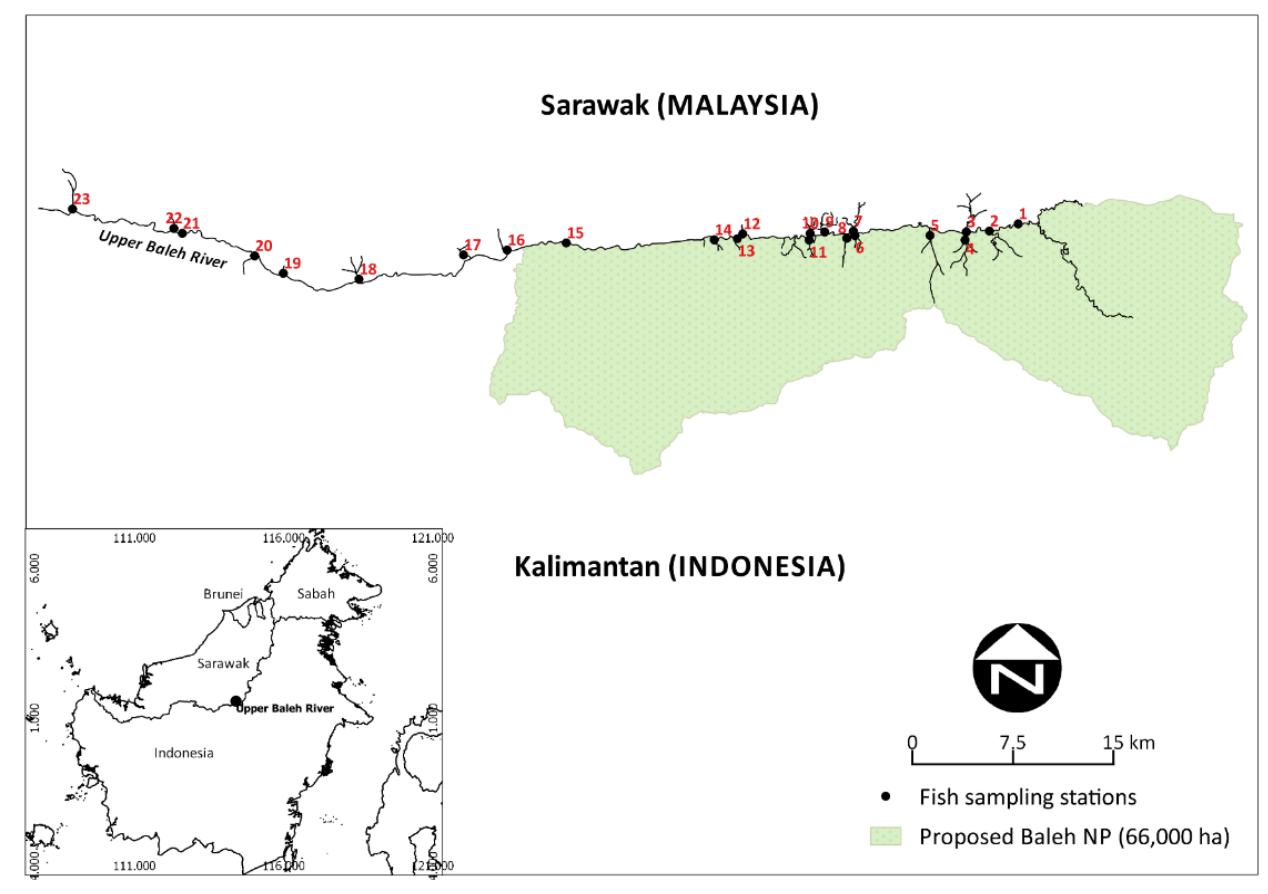

Figure 1. The location of the 23 sampling stations at upper Baleh River, Kapit, Sarawak 
Fish were counted and identified in situ to the species level according to the taxonomic keys available (e.g., Mohsin \& Ambak, 1983; Kottelat \& Tan, 2008; Inger \& Chin, 2002; Roberts, 1989), and an online global species database of fish species (Froese \& Pauly, 2016). Samples that were unidentifiable in the field were fixed in $10 \%$ formalin and preserved in $70 \%$ ethanol for further study in the laboratory. Taxonomics status of the species was also confirmed with Kottelat \& Tan (2008) and Kottelat (2012) and Kottelat (2013). The fresh specimens were measured for standard length (SL), total length (TL) (to the nearest millimeter) and weight (to the nearest gram).

Species diversity, richness and evenness in the whole upper Baleh River and at each station were calculated using the formula below:

Shannon's diversity index (H) (Shannon \& Weaver, 1963),

$$
H=\sum \frac{N_{i}}{N} \log _{e} \frac{N_{i}}{N}
$$

Pielou's evenness (J) (Pielou, 1966), and

$$
J=\frac{H}{\log _{e} S}
$$

Margalef index of species richness (D) (Margalef, 1968),

$$
D=\frac{S-1}{\log _{e} N}
$$

where $\mathrm{N}=$ sample size, $\mathrm{Ni}=$ number of specimen per species, $S=$ total number of species

The fish abundance data were restructured by excluding the fish species that occurred in less than $1 \%$ of the samples. An ordination technique of Canonical Correspondence Analysis (CCA) was used in the direct analyses of the relationships between fish assemblages and environmental parameters (Ter Braak, 1986). Ten environmental parameters were used in the present study. Statistical significance ( $\mathrm{p}$ value $\leq$ 0.05) of the CCA relationships between the set of environmental factors and fish species was evaluated using a permutation test with 999 permutations (Ter Braak \& Verdonschot, 1995). Length-weight relationship (LWR) and general well-being of fish expressed in Fulton's condition factor $(K)$ value of the top three most dominant fish species in the upper Baleh River were determined. The LWR of selected fish species was established using the formula $\mathrm{BW}=\mathrm{aTLn}$ and expressed in the logarithmic form as $\log B W=\log a+n \log T L$ (Le Cren, 1951). The constants 'a' and 'n' were estimated using linear regression analysis. The statistical significance of regression was tested by Analysis of Variance (ANOVA) at $p$ value $\leq 0.05$. The Fulton's condition factor $(\mathrm{K})$ was calculated using the formula $\mathrm{K}=\mathrm{BW}^{*} 100 / \mathrm{TL} 3$ (Pauly, 1983; Binohlan \& Pauly, 1998). CCA was carried out by using the PAleontological STatistics software package (PAST, Palaeontological Association, 2001) whereas all the other statistical analyses were carried out by using the Statistical Software for Social Sciences (SPSS Version 24, SPSS Inc., 1995).

\section{RESULTS AND DISCUSSION}

\section{Fish Assemblage and Species Abundance}

A total of 1,538 specimens comprising 45 species from nine families were captured in the upper Baleh River (Table 1). Eighteen species individually contributed more than $1 \%$ of the total individuals, and collectively accounted for $93.2 \%$ of the total fish caught. The most dominant $(62.9 \%)$ and diverse $(42.2 \%)$ family was Cyprinidae, followed by Balitoridae (31.0\%; $31.1 \%)$. The most dominant species was Tor tambra $(18.1 \%)$ and Lobocheilos ovalis $(12.9 \%)$ from the family Cyprinidae, followed by Parhomaloptera microstoma (11.3\%) from family Balitoridae. Twelve species were extremely low in abundance, with only one or two specimens were caught in the present study, are Acrochordonichthys melanogaster, A. rugosus, Hemibagrus wyckii, Gastromyzon sp. III, Glaniopsis multiradiata, Homalopteroides wassinkii, H. zollingeri, Nemacheilus kapuasensis, Rasbora sp., Macrognathus maculatus, Pangasius macronema and Kryptopterus lais.

Dominance by the family Cyprinidae in the present study is a common pattern, and has been widely reported elsewhere including Malaysia (Jeffrine et al., 2009; Khairul Adha et al., 2009; Nasarudin et al., 2010; Rashid et al., 2015), Thailand (Beamish et al., 2006), Indonesia (Muchlisin \& Siti Azizah, 2009), and South Korea (Jang et al., 2003). The dominance of 
Table 1. Summary of the fish abundance and measurement at the upper Baleh River

\begin{tabular}{|c|c|c|c|c|c|c|c|c|c|}
\hline \multirow{2}{*}{ Family } & \multirow{2}{*}{ Species } & \multicolumn{2}{|c|}{ Fish specimen } & \multicolumn{2}{|c|}{$\begin{array}{l}\text { Total length } \\
(\mathrm{cm})\end{array}$} & \multicolumn{2}{|c|}{$\begin{array}{l}\text { Standard } \\
\text { length }(\mathrm{cm})\end{array}$} & \multicolumn{2}{|c|}{$\begin{array}{l}\text { Body weight } \\
(\mathrm{g})\end{array}$} \\
\hline & & Count & $\%$ & Mean & SD & Mean & SD & Mean & SD \\
\hline Akysidae & $\begin{array}{l}\text { Acrochordonichthys } \\
\text { melanogaster }\end{array}$ & 1 & 0.1 & 13.4 & na & 11.5 & na & 29.8 & na \\
\hline Akysidae & Acrochordonichthys rugosus & 1 & 0.1 & 8.7 & na & 6.7 & na & 5.9 & na \\
\hline \multicolumn{2}{|c|}{ Sub-total number of species } & 2 & 4.4 & & & & & & \\
\hline \multicolumn{2}{|c|}{ Sub-total number of fish caught } & 2 & 0.2 & & & & & & \\
\hline Bagridae & Hemibagrus planiceps & 13 & 0.8 & 19.8 & 5.2 & 15.4 & 4.2 & 77.5 & 59.6 \\
\hline Bagridae & Hemibagrus wyckii & 1 & 0.1 & 37.4 & na & 31.2 & na & 460.0 & na \\
\hline Bagridae & Leiocasis micropogon & 10 & 0.7 & 14.4 & 4.8 & 12.0 & 4.1 & 34.9 & 29.5 \\
\hline Bagridae & Mystus nigriceps & 4 & 0.3 & 24.7 & 2.3 & 19.6 & 1.6 & 101.5 & 21.7 \\
\hline \multicolumn{2}{|c|}{ Sub-total number of species } & 4 & 8.9 & & & & & & \\
\hline \multicolumn{2}{|c|}{ Sub-total number of fish caught } & 28 & 1.8 & & & & & & \\
\hline Balitoridae & Homaloptera orthogoniata & 3 & 0.2 & 9.0 & 0.8 & 7.6 & 0.9 & 5.4 & 1.6 \\
\hline Balitoridae & Homalopteroides tweediei & 3 & 0.2 & 4.1 & 0.3 & 3.4 & 0.4 & 0.6 & 0.1 \\
\hline Balitoridae & Homalopteroides wassinkii & 2 & 0.1 & 4.7 & 0.1 & 3.9 & 0.1 & 1.0 & 0.0 \\
\hline Balitoridae & Homalopteroides zollingeri & 1 & 0.1 & 3.5 & na & 3.0 & na & 0.4 & na \\
\hline Balitoridae & Gastromyzon fasciatus & 82 & 5.3 & 4.3 & 0.9 & 3.5 & 0.7 & 1.2 & 0.7 \\
\hline Balitoridae & Gastromyzon punctulatus & 15 & 1.0 & 4.4 & 1.3 & 3.7 & 1.1 & 2.0 & 1.8 \\
\hline Balitoridae & Gastromyzon sp. I & 6 & 0.4 & 3.6 & 0.3 & 3.2 & 0.9 & 0.9 & 0.8 \\
\hline Balitoridae & Gastromyzon sp. II & 35 & 2.3 & 5.8 & 1.0 & 4.5 & 0.8 & 2.2 & 1.0 \\
\hline Balitoridae & Gastromyzon sp. III & 1 & 0.1 & 4.6 & na & 3.7 & na & 1.4 & na \\
\hline Balitoridae & Glaniopsis multiradiata & 2 & 0.1 & 4.6 & 0.7 & 3.9 & 0.6 & 1.1 & 0.5 \\
\hline Balitoridae & Neogastromyzon chini & 82 & 5.3 & 4.3 & 1.0 & 3.5 & 0.8 & 1.2 & 1.0 \\
\hline Balitoridae & $\begin{array}{l}\text { Neogastromyzon } \\
\text { pauciradiatus }\end{array}$ & 63 & 4.1 & 5.2 & 1.2 & 5.2 & 1.2 & 2.3 & 1.1 \\
\hline Balitoridae & Neogastromyzon sp. & 8 & 0.5 & 3.3 & 0.4 & 2.6 & 0.3 & 0.3 & 0.1 \\
\hline Balitoridae & Parhomaloptera microstoma & 174 & 11.3 & 5.4 & 1.3 & 4.3 & 1.0 & 1.3 & 0.8 \\
\hline \multicolumn{2}{|c|}{ Sub-total number of species } & 14 & 31.1 & & & & & & \\
\hline \multicolumn{2}{|c|}{ Sub-total number of fish caught } & 477 & 31.0 & & & & & & \\
\hline Nemacheilidae & Nemacheilus kapuasensis & 1 & 0.1 & 7.5 & na & 5.4 & na & 2.7 & na \\
\hline Nemacheilidae & Nemacheilus spiniferus & 6 & 0.4 & 7.0 & 1.8 & 5.4 & 1.3 & 2.2 & 1.2 \\
\hline \multicolumn{2}{|c|}{ Sub-total number of species } & 2 & 4.4 & & & & & & \\
\hline \multicolumn{2}{|c|}{ Sub-total number of fish caught } & 7 & 0.5 & & & & & & \\
\hline
\end{tabular}




\section{Continued Table 1}

\begin{tabular}{|c|c|c|c|c|c|c|c|c|c|}
\hline \multirow[t]{19}{*}{ Cyprinidae } & Cyclocheilichthys armatus & 7 & 0.5 & 18.1 & 7.6 & 14.0 & 6.0 & 69.0 & 58.1 \\
\hline & Barbonymus collingwoodii & 67 & 4.4 & 19.9 & 3.2 & 15.0 & 2.3 & 78.6 & 29.7 \\
\hline & Barbonymus schwanenfeldii & 48 & 3.1 & 20.7 & 5.7 & 15.3 & 4.0 & 116.2 & 83.0 \\
\hline & Crossocheilus cobitis & 83 & 5.4 & 5.9 & 1.2 & 4.8 & 0.9 & 2.4 & 1.4 \\
\hline & Cyclocheilichthys apogon & 6 & 0.4 & 16.5 & 2.7 & 12.7 & 2.2 & 47.6 & 18.8 \\
\hline & Hampala bimaculata & 7 & 0.5 & 23.7 & 3.4 & 18.2 & 3.0 & 127.4 & 114.4 \\
\hline & Labiobarbus fasciatus & 5 & 0.3 & 30.7 & 3.3 & 24.1 & 2.1 & 242.0 & 46.0 \\
\hline & Lobocheilos ovalis & 198 & 12.9 & 13.2 & 7.0 & 11.2 & 5.3 & 43.2 & 73.3 \\
\hline & Lobocheilos falcifer & 78 & 5.1 & 13.6 & 6.1 & 11.1 & 4.7 & 36.9 & 56.4 \\
\hline & Luciosoma setigerum & 34 & 2.2 & 27.4 & 2.7 & 21.8 & 2.0 & 121.2 & 46.0 \\
\hline & Luciosoma spilopeura & 4 & 0.3 & 25.8 & 0.5 & 20.3 & 0.6 & 96.3 & 6.3 \\
\hline & Osteochilus schlegelii & 3 & 0.2 & 28.3 & 2.0 & 22.3 & 2.2 & 286.0 & 72.8 \\
\hline & Osteochilus vittatus & 22 & 1.4 & 20.3 & 6.3 & 15.7 & 4.8 & 106.6 & 61.4 \\
\hline & Oxygaster anomalura & 24 & 1.6 & 19.0 & 1.8 & 15.2 & 1.4 & 40.6 & 13.7 \\
\hline & Rasbora borneensis & 80 & 5.2 & 10.7 & 2.3 & 8.5 & 1.9 & 10.1 & 5.0 \\
\hline & Rasbora sp. & 1 & 0.1 & 6.1 & na & 4.7 & na & 1.7 & na \\
\hline & Rasbora rutteni & 4 & 0.3 & 7.2 & 3.5 & 5.7 & 2.8 & 5.7 & 3.4 \\
\hline & Tor tambra & 279 & 18.1 & 13.7 & 8.2 & 11.1 & 6.6 & 63.0 & 140.3 \\
\hline & Tor tambroides & 17 & 1.1 & 16.2 & 6.1 & 13.1 & 5.1 & 48.1 & 53.0 \\
\hline \multicolumn{2}{|c|}{ Sub-total number of species } & 19 & 42.2 & & & & & & \\
\hline \multicolumn{2}{|c|}{ Sub-total number of fish caught } & 967 & 62.9 & & & & & & \\
\hline Mastacembelidae & Macrognathus maculatus & 1 & 0.1 & 25.1 & na & 24.0 & na & 42.4 & na \\
\hline \multicolumn{2}{|c|}{ Sub-total number of species } & 1 & 2.2 & & & & & & \\
\hline \multicolumn{2}{|c|}{ Sub-total number of fish caught } & 1 & 0.1 & & & & & & \\
\hline Pangasiidae & Pangasius macronema & 2 & 0.1 & 35.4 & 3.0 & 28.9 & 2.1 & 277.5 & 74.2 \\
\hline \multicolumn{2}{|c|}{ Sub-total number of species } & 1 & 2.2 & & & & & & \\
\hline \multicolumn{2}{|c|}{ Sub-total number of fish caught } & 1 & 0.1 & & & & & & \\
\hline Siluridae & Kryptopterus lais & 2 & 0.1 & 39.3 & 5.8 & 33.6 & 5.2 & 210.0 & 70.7 \\
\hline \multicolumn{2}{|c|}{ Sub-total number of species } & 1 & 2.2 & & & & & & \\
\hline \multicolumn{2}{|c|}{ Sub-total number of fish caught } & 2 & 0.1 & & & & & & \\
\hline Sisoridae & Glyptothorax major & 52 & 3.4 & 7.8 & 7.0 & 5.7 & 1.7 & 4.7 & 4.4 \\
\hline \multicolumn{2}{|c|}{ Sub-total number of species } & 1 & 2.2 & & & & & & \\
\hline \multicolumn{2}{|c|}{ Sub-total number of fish caught } & 52 & 3.4 & & & & & & \\
\hline \multicolumn{2}{|c|}{ Total number of species } & 45 & 100 & & & & & & \\
\hline \multicolumn{2}{|c|}{ Total number of fish caught } & 1538 & 100 & & & & & & \\
\hline \multicolumn{2}{|c|}{ Shannon's diversity index, H (e) } & 2.9 & & & & & & & \\
\hline \multicolumn{2}{|c|}{ Margalef's richness index, D (e) } & 6.0 & & & & & & & \\
\hline \multicolumn{2}{|c|}{ Pielou's evenness index, $\mathrm{J}(\mathrm{e})$} & 0.8 & & & & & & & \\
\hline
\end{tabular}

Note: "na" indicates not available. 
members of the family Cyprinidae is mostly due to their highly adapted body forms and mouth structure that make them thrive at all environmental conditions (Ward-Campbell et al., 2005). The Balitoridae, which is the second most dominant family in the present study, is typical in high elevation areas, such as that in the upper Baleh River, which consist of mainly montane forest stream habitats. T. tambra which has a high economic value was found to be the most dominant species in the upper Baleh River. However, the much higher valued species, $T$. tambroides was less abundant. Studies have shown that distribution of these species are restricted to upstream and a few protected areas in Malaysia (Litis et al., 1997; Nyanti et al., 1999; Nadiatul et al., 2011). The wild population of these species was low in abundance and distribution particularly in Sarawak due to deforestation, agricultural development, and overfishing (Sungan et al., 2006). In Peninsular Malaysia, Chong et al. (2010) reported that $T$. tambra and $T$. tambroides are highly threatened due to overharvesting, habitat degradation, pollution and damming of rivers. Hence, it is important to retain the upper Baleh River as a living habitat for T. tambra since it was found in abundance in the area.

Fish diversity in the upper Baleh River with a Shannon's diversity index of 2.9 (Table 1 ) is considered moderate (Odum \& Barret, 2004). Species richness of the upper Baleh River with an index value of more than 5 is considered high (Magguran, 1988). The fish assemblages in the upper Baleh River with an evenness index of 0.8 are considered evenly spread (Pielou, 1966). On the other hand, the Shannon's diversity index, Margalef's richness index, and Pielou's evenness index among the 23 stations ranged from 0.4 to 2.6 , from 0.3 to 4.2 , and from 0.6 to 0.9 at main river and tributary stations in the upper Baleh River (Table 2). The variation in the biological indices among the 23 stations might have indicated the species richness and eveness of fish fauna corresponded to the size and quality of the streams. All three indices fluctuated at tributary stations along the upper Baleh River but showed sign of an increase at the main river. Eighteen stations were categorized as 'low' diversity (<2) (Odum \& Barret, 2004). Five stations were categorized as having 'moderate' diversity (2-4) which include three stations located at the main river and two tributary stations (Sg. Sengayuh and Sg. Bekakap). The highest species richness was found at Station 21 which was located at the lower part of the Baleh River followed by a tributary station at $\mathrm{Sg}$. Bekakap. The richness index at these two stations were more than 3.5 and thus categorized as 'moderate' whereas all the other stations were categorized as 'low' species richness (Magguran, 1988). The fish assemblages are considered evenly spread over most of the stations in the upper Baleh River where 20 out of 23 stations had an evenness index of 0.7 and above (Pielou, 1966).

\section{Environmental Influences on Fish Assemblages}

Eighteen species that individually contributed more than $1 \%$ of the total fish caught and 10 environmental parameters were loaded in the CCA. Table 3 summarized the ten environmental parameters used in the present study. The first CCA axis (CCA1) had an eigenvalue of 0.590 and explained $27.2 \%$ of the species-environment relation variance. The CCA 2 and CCA3 accounted for $20.7 \%$ and $15.7 \%$ of total variance with eigenvalues of 0.448 and 0.341 , respectively. These three axes were statistically significant ( $p$ value $\leq 0.05$ ) according to the permutation test. The CCA1 was negatively correlated with elevation and positively correlated with stream order and sedimentation. Five species including Barbonymus collingwoodii, B. schwanefeldii, Luciosoma setigerum, Osteochilus vittatus, and Oxygaster anomalura from family Cyprinidae had positive loadings on CCA1 and grouped together at the right portion of the CCA ordination triplot (Figure 2). This indicates that fishes in these assemblages live in the lower part of relatively larger streams and can tolerate sedimentation. Figure 2 also illustrates that those species were found abundant at stations 1,15 , and 21 which were located at the main river and stations 19 and 20 which were located at downstream. On the other hand, Neogastromyzon chini from family Gastromyzontidae was negatively loaded on CCA1 which indicates that the fish is living in the hilly area at the upper Baleh River with high elevation and low sedimentation. This is not surprising as fishes from the Gastromyzontidae family are often referred to as 'hill stream loaches', due to their ability to cope with fast flowing waters (Roberts, 1989). Stream order, loaded on CCA2. Among the 18 species, Gastromyzon fasciatus, G. punctulatus, and 
Table 2. Fish biological indices in the upper Baleh River

\begin{tabular}{llccccc}
\hline Station & River & Individual & Species & H (e) & D (e) & J (e) \\
\hline 1 & Btg Baleh (upper) & 92 & 15 & 2.0 & 3.1 & 0.7 \\
2 & Sg. Entakun & 76 & 5 & 1.3 & 0.9 & 0.8 \\
3 & Sg. Singut & 49 & 9 & 1.9 & 2.1 & 0.9 \\
4 & Sg. Puun & 70 & 3 & 1.0 & 0.5 & 0.9 \\
5 & Sg. Jambu & 21 & 2 & 0.4 & 0.3 & 0.6 \\
6 & Sg. Naah & 63 & 6 & 1.5 & 1.2 & 0.8 \\
7 & Sg. Selentang & 71 & 5 & 1.4 & 0.9 & 0.9 \\
8 & Sg. Penganen & 94 & 9 & 1.5 & 1.8 & 0.7 \\
9 & Sg. Senentang Kanan & 27 & 6 & 1.4 & 1.5 & 0.8 \\
10 & Sg. Sebatu & 33 & 10 & 1.9 & 2.6 & 0.8 \\
11 & Sg. Irak & 163 & 9 & 1.8 & 1.6 & 0.8 \\
12 & Sg. kerangan & 92 & 8 & 1.3 & 1.5 & 0.6 \\
13 & Sg. Tor & 96 & 5 & 1.4 & 0.9 & 0.9 \\
14 & Sg. Kian & 166 & 8 & 1.5 & 1.4 & 0.7 \\
15 & Btg Baleh (middle) & 51 & 14 & 2.1 & 3.3 & 0.8 \\
16 & Sg. Sengayuh & 21 & 10 & 2.1 & 3.0 & 0.9 \\
17 & Sg. Nibong & 46 & 9 & 1.6 & 2.1 & 0.7 \\
18 & Sg. Bekakap Besar & 33 & 6 & 1.1 & 1.4 & 0.6 \\
19 & Sg. Bekakap & 80 & 17 & 2.3 & 3.7 & 0.8 \\
20 & Sg. Kuran & 25 & 5 & 1.0 & 1.2 & 0.7 \\
21 & Btg Baleh (lower) & 123 & 21 & 2.6 & 4.2 & 0.8 \\
22 & Ng. Nangsang & 13 & 6 & 1.7 & 1.9 & 0.9 \\
23 & Sg. Sekawai & 33 & 10 & 1.8 & 2.6 & 0.8 \\
\hline
\end{tabular}

Crossocheilus cobitis were positively loaded on CCA2 and grouped together at the upper part of the first CCA ordination triplot whereas Gastromyzon sp. II, Neogastromyzon chini, Rasbora borneensis, and Glyptothorax major were negatively correlated with CCA2 and grouped together at the lower part of the first CCA ordination triplot (Figure 2). These results indicate that the first three species were mostly found at relatively larger streams with higher $\mathrm{pH}$ and temperature value, while the latter four fish species mostly inhabit at smaller tributaries with lower $\mathrm{pH}$ and temperature. The CCA3 was positively correlated with canopy cover and habitat assessment score point and negatively correlated with turbidity. Fish species that are positively correlated with CCA3 prefer to live in a stream with better habitat condition which include greater shade and low turbidity. Gastromyzon sp. II, G. fasciatus, G. punctulatus, Lobocheilos falcifer and Rasbora borneensis are those species that were found positively correlated with CCA3 in the present study. On the other hand, Neogastromyzon chini, $N$. pauciradiatus, and T. tambroides were found negatively loaded on CCA3 indicating that they might be more tolerant to the poorer habitat.
Lastly, T. tambra, L. ovalis, and P. microstoma which are the top three most dominant species in the present study were comparatively distributed more around the centre of the triplot than the other species (Figure 2), indicating that they are living in a wide-ranging environment. It is hypothesized that adaptation of these fishes to a great variation of habitats occupied may be associated with their abundance at the upper Baleh River.

\section{Length-weight Relationship (LWR) and Fulton's Condition Factor (K)}

The Gastromyzon chini was the smallest fish species captured in the upper Baleh River, with mean values of TL and BW of $3.3 \pm 0.4 \mathrm{~cm}$ and $0.3 \pm 0.1 \mathrm{~g}$, respectively. Kryptopterus lais had the greatest length, $39.3 \pm 5.8 \mathrm{~cm}$ in TL, while the heaviest fish captured was Hemibagrus wyckii (460.0 g) (Table 1). The LWR study was conducted on the top three most dominant species in the present study. The linear regression analysis showed significant $R^{2}$ values ( $p$ value $\leq 0.05$ ), ranging from 0.934 to 0.977, indicating that TL and BW of each of the species fitted well into the linear model (Table 4). The LWR for T. tambra, L. ovalis, and 
Table 3. Ten environmental parameters in the upper Baleh River

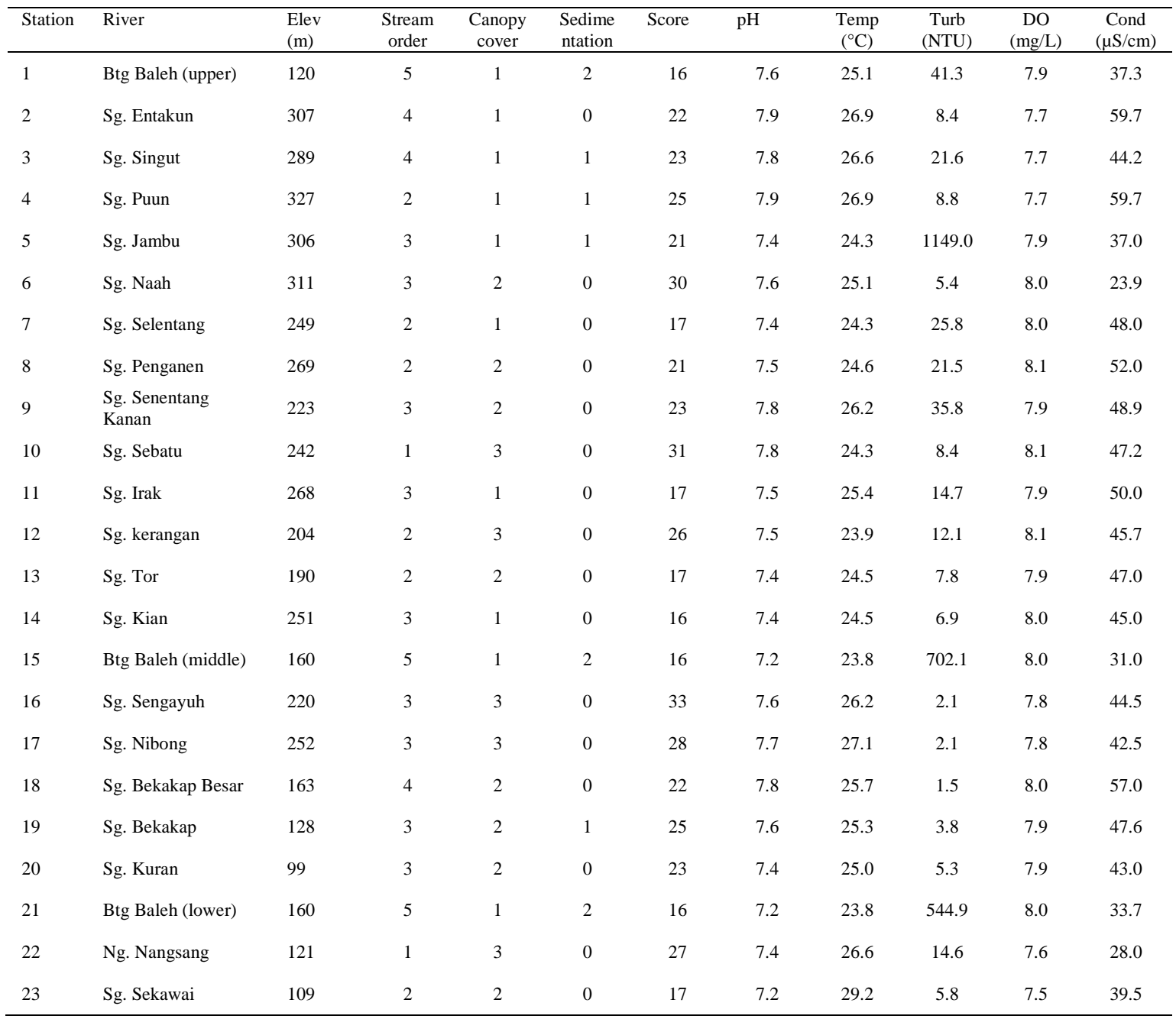

P. microstoma in the upper Baleh River was determined as $\mathrm{W}=0.013 \mathrm{~L}^{2.919}, \mathrm{~W}=0.020 \mathrm{~L}^{2.719}$ and $\mathrm{W}=0.005 \mathrm{~L}^{3.153}$ respectively. The coefficient ' $\mathrm{n}$ ' value for T. tambra and L. ovalis of less than 3 indicates that they were exhibiting a negative allometric growth. On the other hand, $P$. microstoma grew heavier in the upper Baleh River as indicated by the ' $n$ ' value of more than 3 . All ' $n$ ' values in the present study fall within the range of 2.5 to 3.5 for most fish (Froese, 2006).

Interestingly, the most dominant species, $T$. tambra, and the second most dominant species, L. ovalis, exhibited negative allometric growth, while the third most dominant species, $P$. microstoma exhibited a positive allometric growth. Food availability, environmental conditions or other life-history strategies could be reasons for the different growth patterns exhibited by these species. Competition for food may occur when T. tambra and L. ovalis are in abundance. On the other hand, a mountainous forest stream in the present study area is considered to be a more suitable environmental condition for $P$. microstoma, since the Gastromyzontidae family is typical in high elevation areas.

The Fulton's condition factors $(\mathrm{K})$ of $T$. tambra, L. ovalis, and P. microstoma were 1.07 $\pm 0.30,1.13 \pm 0.49$, and $0.70 \pm 0.22$, respectively, in the upper Baleh River (Table 5). More than $80 \%$ of $\mathrm{K}$ values of $T$. tambra were found in the range between 0.8 and 1.2 which indicates that most of the fish in this species were in fair to poor conditions. More than $70 \%$ of $\mathrm{K}$ values of $L$. ovalis were found to be less than 1.0 , 

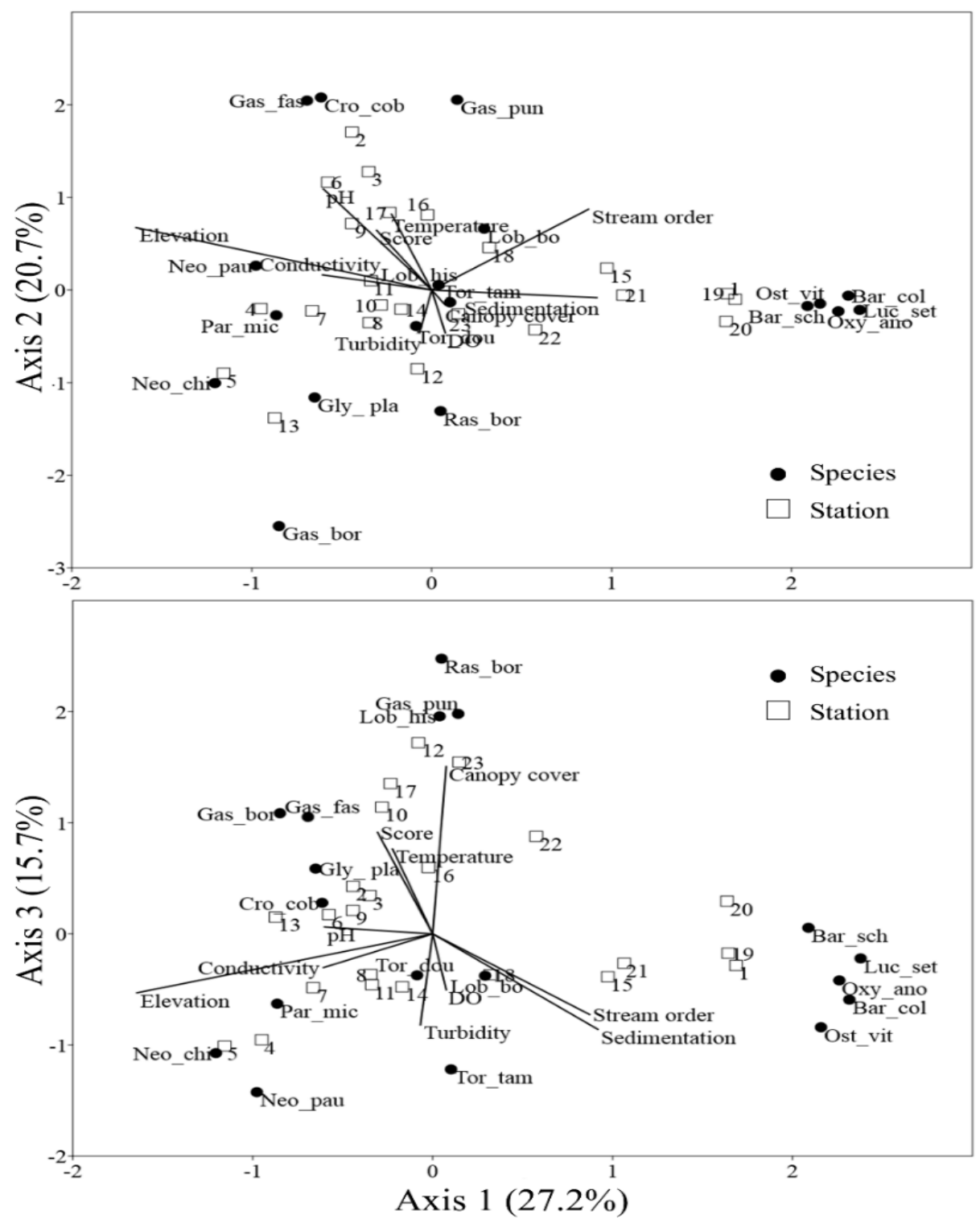

Figure 2. CCA ordination triplots of the abundance of the 18 species (>1\%) with ten environmental parameters at 23 stations in the upper Baleh River. Gas_bor = Gastromyzon sp. II, Gas_fas = G. fasciatus, Gas_pun = G. punctulatus, Neo_chi $=$ Neogastromyzon chini, Neo_pau $=N$. pauciradiatus, Par_mic $=$ Parhomaloptera microstoma, Bar_col = Barbonymus collingwoodii, Bar_sch = B. schwanefeldii, Cro_cob = Crossocheilus cobitis, Lob_bo = Lobocheilos ovalis, Lob_his $=$ L. falcifer, Luc_set $=$ Luciosoma setigerum, Ost_vit $=$ Osteochilus vittatus, Oxy_ano = Oxygaster anomalura, Ras_bor = Rasbora borneensis, Tor_dou = Tor tambra, Tor_tam $=T$. tambroides, Gly_pla = Glyptothorax major

indicating that they were in poor to extremely poor conditions. Most of the P. microstoma $(85.1 \%)$ were found to be less than 0.8 in $\mathrm{K}$ values, indicating that they were in extremely poor condition (Barnham \& Baxter, 1998). The value of $\mathrm{K}$ is influenced by season, age, sex, and gonad development of the fish, feeding and stomach fullness, as well as proximate body composition (Le Cren, 1951; Mohsin \& Ambak,
1983; Barnham \& Baxter, 1998; Schneider et al., 2000; Gupta et al., 2011; Mozsar et al., 2015). Since water samples taken from the upper Baleh River contained high suspended solids, particularly after rain (Ling et al., 2016), exposure to high turbidity and suspended solids could have reduced their feeding rate and growth (Bergstedt \& Bergersen, 1997; Rowe \& Dean, 1998; Lake \& Hinch, 1999). 
Table 4. Summary of regression analyses of length-weight relationship of the top three dominant species in the upper Baleh River

\begin{tabular}{|c|c|c|c|c|c|c|c|c|c|c|}
\hline \multirow[b]{2}{*}{ Species } & \multicolumn{3}{|c|}{$\log B W=\log a+n \log T L$} & \multirow{2}{*}{\multicolumn{2}{|c|}{$\begin{array}{l}\text { Parameter } \\
\text { estimates }\end{array}$}} & \multirow{2}{*}{$\begin{array}{l}\text { Standard } \\
\text { error }\end{array}$} & \multirow[b]{2}{*}{$p$ value } & \multicolumn{2}{|c|}{$\begin{array}{l}95.0 \% \text { confidence } \\
\text { interval }\end{array}$} & \multirow[b]{2}{*}{ LWR: $\mathrm{W}=\mathrm{aL}^{\mathrm{n}}$} \\
\hline & $\mathrm{N}$ & $\mathrm{R}^{2}$ & $p$ value & & & & & $\begin{array}{l}\text { Lowe } \\
\mathrm{r} \\
\text { bound }\end{array}$ & Upper bound & \\
\hline \multirow[t]{2}{*}{ Tor tambra } & 279 & 0.977 & 0.000 & $\mathrm{a}$ & -1.891 & 0.029 & 0.000 & $-\overline{1.948}$ & -1.833 & \multirow[t]{2}{*}{$\mathrm{W}=0.013 \mathrm{~L}^{2.919}$} \\
\hline & & & & $\mathrm{n}$ & 2.919 & 0.027 & 0.000 & 2.866 & 2.971 & \\
\hline \multirow[t]{2}{*}{$\begin{array}{l}\text { Lobocheilos } \\
\text { ovalis }\end{array}$} & 198 & 0.934 & 0.000 & $\mathrm{a}$ & -1.704 & 0.056 & 0.000 & - & -1.594 & \multirow[t]{2}{*}{$\mathrm{W}=0.020 \mathrm{~L}^{2.719}$} \\
\hline & & & & $\mathrm{n}$ & 2.719 & 0.052 & 0.000 & 2.618 & 2.821 & \\
\hline \multirow[t]{2}{*}{$\begin{array}{l}\text { Parhomaloptera } \\
\text { microstoma }\end{array}$} & 174 & 0.938 & 0.000 & $\mathrm{a}$ & -2.280 & 0.045 & 0.000 & $\begin{array}{l}- \\
2.369\end{array}$ & -2.191 & \multirow[t]{2}{*}{$\mathrm{W}=0.005 \mathrm{~L}^{3.153}$} \\
\hline & & & & $\mathrm{n}$ & 3.153 & 0.062 & 0.000 & 3.031 & 3.274 & \\
\hline
\end{tabular}

Table 5. Summary of Fulton's condition factor (K) of the top three dominant species in the upper Baleh River

\begin{tabular}{|c|c|c|c|c|c|c|c|c|c|c|c|}
\hline \multirow{2}{*}{ Species } & \multirow{2}{*}{$\mathrm{N}$} & \multicolumn{4}{|c|}{ Fulton's condition factor $(\mathrm{K})$} & \multicolumn{6}{|c|}{ Percentages of individual } \\
\hline & & Min & Max & Mean & $\mathrm{SD}$ & $\leq 0.8$ & $0.8<\mathrm{x} \leq 1$ & $1<x \leq 1.2$ & $1.2<\mathrm{x} \leq 1.4$ & $1.4<\mathrm{x} \leq 1.6$ & $>1.6$ \\
\hline Tor tambra & 279 & 0.27 & 2.49 & 1.07 & 0.30 & 2.5 & 44.1 & 37.6 & 6.5 & 1.1 & 8.2 \\
\hline $\begin{array}{l}\text { Lobocheilos } \\
\text { ovalis }\end{array}$ & 198 & 0.54 & 2.95 & 1.13 & 0.49 & 36.4 & 34.3 & 6.6 & 0.0 & 0.5 & 22.2 \\
\hline $\begin{array}{l}\text { Parhomalopte } \\
\text { ra microstoma }\end{array}$ & 174 & 0.25 & 2.88 & 0.70 & 0.22 & 85.1 & 12.6 & 0.6 & 1.1 & 0.0 & 0.6 \\
\hline
\end{tabular}

\section{CONCLUSION}

The fish assemblages in the upper Baleh River are moderately diverse and rich in species, the richness values spread evenly along the river. Environmental parameters including elevation, stream order, and sedimentation were the most significant factors related to the fish assemblages in the river. The three most dominant fish species were T. tambra $(18.1 \%)$ and L. ovalis $(12.9 \%)$ from the Cyprinidae family, followed by $P$. microstoma (11.3\%) from the Balitoridae family. Length-weight relationship analysis showed that the first two species exhibited a negative allometric growth pattern while the latter exhibited a positive allometric growth pattern. All of them did not show healthy conditions, according to the Fulton's condition factor. It is suggested that various factors including food competition and environmental condition could have contributed to the different growth pattern and condition of these fishes. Further studies need to be conducted to investigate the underlying factors that are affecting the fish's health in the upper Baleh River.

\section{ACKNOWLEDGEMENTS}

The authors would like to thank Forest Department Sarawak and Institute of Biodiversity and Environmental Conservation, Universiti Malaysia Sarawak for organizing the expedition in November 2015, Sarawak Energy Berhad for the financial assistance, and Mustapha Kamal, Lai Wei Sing and Chai Hui Ping for their field assistance. Data collected in April 2015 was made possible by the financial assistance of Sarawak Energy Berhad through Grant No. GL(F07)/SEB/1A/2013 (12) and is gratefully acknowledged.

\section{REFERENCES}

Atack, K. (2006). A field guide to the fishes of Kuching Rivers, Sarawak, Malaysian Borneo. Natural History Publications (Borneo) Sdn Bhd, Kota Kinabalu, Pp. 200.

Barbour, M.T., Gerritsen, J., Griffith, G.E., Frydenborg, R., McCarron, E., White, J.S. \& Bastian, L. (1996). A framework for biological criteria for Florida streams using benthic macroinvertebrates. Journal of the North American Benthological Society, 15: 185-211. 
Barnham, C. \& Baxter, A. (1998). Condition factor, $\mathrm{K}$, for salmonid fish. Fisheries Notes, 1-3.

Beamish, F.W.H., Sa-Ardrit, P. \& Tongnunui, S. (2006). Habitat characteristics of the Cyprinidae in small rivers in central Thailand. Environmental Biology of Fishes, 76(2-4): 237-253.

Bergstedt, L. \& Bergersen, E. (1997). Health and movements of fish in response to sediment sluicing in the Wind River, Wyoming. Canadian Journal of Fisheries and Aquatic Sciences, 54: 312-319.

Binohlan, C. \& Pauly, D. (1998). The length-weight table. In Froese, R. \& Pauly, D. (eds.), Fishbase 1998: Concepts, Design and Data Sources. ICLARM, Manila, Pp. 121-123.

Chong, V.C., Lee, P.K.Y. \& Lau, C.M. (2010). Diversity, extinction and conservation of Malaysian fishes. Journal of Fish Biology, 76(9): 2009-2066.

Dudgeon, D. (2000). Large-scale hydrological changes in tropical Asia: Prospects for riverine biodiversity. BioScience, 50(9): 793-806.

Froese, R. \& Pauly, D. (Editors) 2016. FishBase. World Wide Web electronic publication. www.fishbase.org, version (10/2016).

Froese, R. (2006). Cube law, condition factor and weight-length relationships: History, metaanalysis and recommendations. Journal of Applied Ichthyology, 22(4): 241-253.

Gupta, B.K., Sarkar, U.K., Bhardwaj, S.K. \& Pal, A. (2011). Condition factor, length-weight and length-weight relationships of an endangered fish Ompok pabda (Hamilton 1822) (Siluriformes: Siluridae) from the River Gomti, a tributary of the River Ganga, India. Journal of Applied Ichthyology, 27: 962-964.

Inger, R.F. \& Chin, P.K. (2002). The Freshwater Fishes of North Borneo. (Revised 2002 edition with supplementary chapter by P.K. Chin). Kota Kinabalu: Natural History Publications (Borneo).

Iwata, T., Nakano, S. \& Inoue, M. (2003). Impacts of past riparian deforestation on stream communities in a tropical rain forest in Borneo. Ecological Application, 13(2): 461-473.

Jang, M.H., Lucas, M.C. \& Joo, G.J. (2003). The fish fauna of mountain streams in South Korean national parks and its significance to conservation of regional freshwater fish biodiversity. Biological Conservation, 114(1): 115-126.
Jeffrine, R.R., Dennis, K.P., Khairul Adha, A.R. \& Esa Y. (2009). Freshwater fishes of Layar and Spak Rivers, Betong, Sarawak. Malaysian Fisheries Journal, 8(1): 35-42.

Khairul Adha, A.R., Daud, S.K., Siraj, S.S., Arshad, A., Esa, Y. \& Ibrahim, E.R. (2009). Freshwater fish diversity and composition in Batang Kerang Floodplain, Balai Ringin, Sarawak. Pertanika Journal Tropical Agricultural Science, 32 (1): 7 16.

Kottelat, M. (2012). Conspectus cobitidum: an inventory of the loaches of the world (Teleostei: Cypriniformes: Cobitoidei). Raffles Bulletin of Zoology, Supplement 26: 1-199.

Kottelat, M. (2013). The fishes of the inland waters of Southeast Asia: A catalogue and core bibliography of the fishes known to occur in freshwaters, mangroves and estuaries. Raffles Bulletin of Zoology, Supplement 27: 1-663.

Kottelat, M. \& Lim, K.K.P. (1995). Freshwater fishes of Sarawak and Brunei Darussalam: a preliminary annotated checklist. Sarawak Museum Journal, 48: 227-256.

Kottelat, M. \& Tan, H.H. (2008). A synopsis of the genus Lobocheilos in Java, Sumatra and Borneo, with descriptions of six new species (Teleostei: Cyprinidae). Ichthyological Exploration of Freshwaters, 19(1): 27-58.

Kottelat, M. \& Whitten, T. (1996). Freshwater biodiversity in Asia with special reference to fish. World Bank Technical Paper. Washington, DC: World Bank.

Lake, R.G. \& Hinch, S.G. (1999). Acute effects of suspended sediment angularity on juvenile coho salmon (Oncorhynchus kisutch). Canadian Journal of Fisheries and Aquatic Sciences, 56: 862-867.

Le Cren, E.D. (1951). The length-weight relationship and seasonal cycle in gonad weight and conditions in the perch (Perca fluviatilis). Freshwater Biological Association, 20(2): 201-219.

Lelek, A. (1987). Freshwater and swamp fisheries on the Rajang River, Sarawak, Malaysia. Archiv für Hydrobiologie - BeiheftErgebnisse der Limnologie, 28: 247-260.

Ling, T.Y., Soo, C. L., Sivalingam, J.R., Nyanti, L., Sim, S.F. \& Grinang, J. (2016). Assessment of the water and sediment quality of tropical forest streams in upper reaches of Baleh River, Sarawak, Malaysia, subjected to logging activities. Journals of Chemistry, 2016: 1-13. 
Litis, B.A., Sungan, S., Jugang, K., Ibrahim, M. \& Bini, H.A. (1997). Features of indigenous fish species having potential for aquaculture. Inland Fisheries Division, Department of Agriculture, Sarawak.

Magurran, A.E. (1988). Ecological Diversity and Its Measurement. Croom Helm, London. 179 pp.

Margalef, R. (1968). Perspectives in Ecological Theory. University of Chicago Press, Chicago.

Mohsin, A.K.M. \& Ambak, M.A. (1983). Freshwater Fishes of Peninsular Malaysia. Penerbit Universiti Pertanian Malaysia, Serdang. 284 pp.

Mozsár, A., Boros, G., Sály, P., Antal, L. \& Nagy, S. A. (2015). Relationship between Fulton's condition factor and proximate body composition in three freshwater fish species. Journal of Applied Ichthyology, 31(2): 315-320.

Muchlisin, Z.A. \& Siti Azizah, M.N. (2009). Diversity and distribution of freshwater fishes in Aceh water, northern Sumatra, Indonesia. International Journal of Zoological Research, 5(2): 67-79.

Nadiatul, H.H., Daud, S.K., Siraj, S.S., Sungan, S. \& Moghaddam, F.Y. (2011). Genetic diversity of Malaysian indigenous Mahseer, Tor douronensis in Sarawak river basins as revealed by cytochrome c oxidase I gene sequences. Iranian Journal of Animal Biosystematics, 7: 119-127.

Nasarudin, M.H., Ruhana, H. \& Farah, A.E. (2010). Fish assemblages in Nanga Merit Area, Kapit, Sarawak. Reprinted from the Sarawak Museum Journal, 67 (8): 275-284.

Nyanti, L., Ling, T.Y. \& Khairul Adha, A.R. (1999). Freshwater fishes from Bario, Kelabit Highlands, Sarawak. ASEAN Review of Biodiversity and Environmental Conservation (ARBEC), pp. 1-6.

Odum, E.P. \& Barret, G.W. (2004). Fundamental of Ecology. Belmont: Thomson Brooks Cole Publishing. $624 \mathrm{pp}$.

Parenti, L.R. \& Lim, K.K.P. (2005). Fishes of the Rajang Basin, Sarawak, Malaysia. The Raffles Bulletin of Zoology, 13: 175-208.

Pauly, D. (1983). Some Simple Methods for the Assessment of Tropical Fish Stocks. FAO. Fisheries Technical Paper (234) FAO, Rome.

Pielou, E.C. (1966). Species diversity and pattern diversity in the study of ecological succession. Journal of Theoretical Biology, 10:370-383.
Rashid, Z.A., Asmuni, M. \& Amal, M.N.A. (2015). Fish diversity of Tembeling and Pahang rivers, Pahang, Malaysia. Check List, 11(5): 1-6.

Roberts, T.R. (1989). The Freshwater Fishes of Western Borneo (Kalimantan Barat, Indonesia). San Francisco: California Academy of Sciences, 14: $1-210$.

Rowe, D.K. \& Dean, T.L. (1998). Effects of turbidity on the feeding ability of the juvenile migrant stage of six New Zealand freshwater fish species. New Zealand Journal of Marine and Freshwater Research, 32: 21-29.

Schneider, J.C., Laarman, P.W. \& Gowing, H. (2000). Manual of Fisheries Survey Methods II: with periodic updates. In JC Schneider (Ed.), Lengthweight relationships. Ann Arbor: Michigan Department of Natural Resources.

Shannon, C.E. \& Weaver, W. (1963). The mathematical theory of communication. University of Illinois Press, Urbana.

Sungan, S., Tinggi, D., Salam, N. \& Sadi, C. (2006). Aspects of the biology and ecology of empurau (Tor tambroides) and semah (Tor douronensis) in Sarawak, Malaysia. In: Mahseer 2006. International Symposium on the Mahseer (Kuala Lumpur, Malaysia). 29-30 March 2006 (ed. By Anon). Malaysian Fisheries Society, Kuala Lumpur. Pp. 3.

Ter Braak, C.J.F. (1986). Canonical correspondence analysis: A new eigenvector technique for multivariate direct gradient analysis. Ecology, 67:1167-1179.

Ter Braak, C.J.F. \& Verdonschot, P.F.M. (1995). Canonical correspondence analysis and related multivariate methods in aquatic ecology. Aquatic Sciences, 57: 255-289.

Teresa, F.B., Casatti, L. \& Cianciaruso, M.V. (2015). Functional differentiation between fish assemblages from forested and deforested streams. Neotropical Ichthyology, 13(2): 361-370.

Ward-Campbell, B.M.S., Beamish, F.W.H. \& Kongchaiya, C. (2005). Morphological characteristics in relation to diet in five coexisting Thai fish species. Journal of Fish Biology, 67(5): 1266-1279. 